\title{
Literatur Review : Hubungan Pemberian Inisiasi Menyusu Dini (IMD) Dengan Kelancaran Pengeluaran Asi
}

\author{
Dewi Solekha1*, Emi Nurlaela \\ ${ }^{1,2}$ Program Studi Sarjana Keperawatan, Universitas Muhammadiyah Pekajangan Pekalongan, \\ Indonesia \\ *email:dewisolekha275@gmail.com
}

\begin{abstract}
The infant mortality rate in Indonesia is still high at 24 per 100 live births. One of the causes is infection. Infection can by prevented by controling breast milk because breast milk contains colostrum which is able to maintain the baby's immune system. The introduction of breastfeeding begins with early initiation of breastfeeding. The coverage of newsborn in Indonesia in 2019 who received early intiation of breastfeeding was 75,58\%. The purpose of this study was to determine the between early initiation of breastfeeding and the smooth production of breast milk throught the Literature Review. This reserch is a quantitive research through Literature Review. The articles were obtained from three articles from articles from Garuda Portal which is a critical review of the JBI instrument written by The Joanna Briggs Institute. The results of this study indicate a relationship between the provion of early intitiation og breastfeeding with the smooth discharge of breast milk with $\mathrm{p}$ value $<0,05$ $(0,000-0,029)$. There is a corelation between the previsions of early initiation of breastfeeding the smoothness is producing breast milk.
\end{abstract}

Keywords :giving early initiation of breastfeeding ( IMD), breast milk flow

\begin{abstract}
Abstrak
Angka kematian bayi di Indonesia masih tinggi yaitu 24 per 1000 kelahiran hidup. Salah satu penyebabnya yaitu infeksi. Infeksi dapat dicegah dengan pengendalian ASI karena didalam ASI mengandung kolostrum yang mampu menjaga daya tahan tubuh bayi. Pengenalan Asi dimulai dengan inisiasi menyusu dini (IMD).Cakupan bayi baru lahir di Indonesia pada tahun 2019 yang mendapatkan Inisiasi Menyusu Dini ( IMD) yaitu 75,58. Tujuan dari penelitian ini adalah untuk mengetahui hubungan pemberian Inisiasi Menyusu Dini dengan kelancaran Pengeluaran ASI melalui Literatur Review. Penelitian ini merupakan Penelitian kuantitatif melalui Literature Review. Artikel didapatkan dari Searh Ergine Google scholar tiga dan Portal Garuda dua telaah kritis instrument JBI The Joanna Briggs Institute .Hasil penelitian ini menunjukkan adanya hubungan antara pemberian inisiasi menyusu dini (IMD) dengan kelancaran pengeluaran ASI dengan $\mathrm{p}$ value $<0,05(0,000-0,029)$. Terdapat hubungan antara pemberian inisiasi menyusu dini (IMD) dengan kelancaran pengeluaran ASI.
\end{abstract}

Kata kunci: Pemberian IMD ; Kelancaran Pengeluaran ASI.

\section{Pendahuluan}

Angka kematian bayi (AKB) merupakan indikator terpenting bagi sebuah Negara sebagai acuan untuk menentukan derajat kesehatan masyarakat, Pada tahun 2019 di Indonesia angka kematian bayi mencapai 24 per 1.000 kelahiran hidup (Kemenkes, 2020). 8,2 per 1.000 kelahiran hidup di Provinsi Jawa Tengah serta 12 per 1000 kelahiran hidup di kota Pekalongan dan 8,7 per 1.000 kelahiran hidup di kabupaten 


\section{Prosiding Seminar Nasional Kesehatan 2021 Lembaga Penelitian dan Pengabdian Masyarakat Universitas Muhammadiyah Pekajangan Pekalongan}

Pekalongan (Dinkes Jateng, 2020). Penyebab tingginya angka kematian bayi di Indonesia salah satunya yaitu sepsis neonatorum 10,2 persen, penyakit infeksi dan parasit 7,1 persen (Djaja, dkk 2012). Air susu ibu (ASI) Eksklusif mengandung kolostrum yang kaya akan antibodi karena mengandung protein untuk daya tahan tubuh dan bermanfaat untuk mematikan kuman dalam jumlah tinggi sehingga pemberian ASI Eksklusif dapat mengurangi resiko angka kematian bayi [1]

Air susu ibu ( ASI ) Eksklusif berdasarkan peraturan pemerintahan Nomor 33 tahun 2012 tentang pemberian Air Susu Ibu Eksklusif adalah ASI yang diberikan kepada bayi sejak dilahirkan selama enam bulan, tanpa menambahkan atau mengganti dengan makanan minuman lain kecuali obat, vitamin dan mineral (Dinkes Jateng, 2019). ASI adalah cairan putih yang dihasilkan payudara ibu melalui proses menyusui, ASI merupakan makanan yang terbaik untuk bayi yang telah disiapkan oleh ibu pada masa kehamilan. pada masa kehamilan ibu, hormon tertentu merangsang payudara untuk memperbanyak saluran-saluran air susu dan kelenjar-kelenjar air susu tersebut, kemudian ASI masuk ke dalam saluran penampung ASI dekat putting melalui saluran saluran air susu (ductus) dan akan disimpan sementara di dalam penampungan sampai tiba bayi menghisap melalui putting [2]

Pemberian ASI merupakan metode pemberian makanan terbaik, terutama pada bayi kurang dari 6 bulan.ASI mengandung berbagai zat gizi atau cairan yang dibutuhkan untuk mencukupi bayi pada 6 bulan pertama setelah kelahiran, tidak hanya mengandung rangkaian asam lemak tak jenuh yang sangat penting perkembangan otak. ASI mudah dicerna dan diresap karena mengandung enzim pencernaaan, ASI juga dapat, mencegah terjadinya penyakit infeksi lantaran mengandung zat penangkal penyakit, yakni immunoglobulin [3] Immunoglobulin A yakni ASI berwarna kekuningan yang keluar pertama dari payudara.zat ini melindungi bayi dari serangan infeksi. IgA melapisi saluran cerna agar kuman tidak dapat masuk kedalam aliran darah dan akan melindungi bayi sehingga sistem kekebalan tubuhnya berfungsi dengan baik [4]

Aspek psikologis, pemberian ASI secara total akan mempereraat hubungan mental ibu dan anak, yang sangat bermanfaat bagi perkembangan mental dan emosional anak selanjutnya. sikap daan cara ibu yang menyusui mencerminkan curahan kasih sayang dan perlindungan kepada anak untuk anak, sikap serta pelukan ibu saat menyusi itu memberikan rasa aman, nyaman dan sejahtera baginya. Sementara ibu merasakan kodratnya serta naluri keibunya akan tersalurkan dengan cara memberikan ASI pada bayinya, sehingga akan memberikan kepuasan tersendiri baginya (Wulan,2011).

Kelancaran pemberian ASI Eksluksif pada ibu untuk anaknya dapat dilihat dari keyakinan pada ibu, keyakinan dan sikap positif yang ibu tunjukkan dan rasa semangat pada ibu untuk memberikan ASI Eksluksif pada bayi juga sangat berpengaruh dalam kebehasilan dalam pemberian ASI Eksluksif itu sendiri. Beberapa kriteria yang dipakai sebagai patokan untuk mengetahui jumlah ASI lancar atau tidak adalah : ASI yang banyak dapat merembes keluar melalui putting, sebelum disusukan payudara terasa tegang, jika ASI cuukup setelah menyusu bayi akan tertidur/tenang selama 3-4 jam, sebelum menyusui payudara terasa penuh dan setelah menyusui terasa longgar, bayi kencing lebih sering sekitar 8 kali dalam 24 jam, bayi yang mendapatkan ASI memadai umumnya kebih tenang, tidak rewel dan dapat tidur pulas [5] 


\section{Prosiding Seminar Nasional Kesehatan Lembaga Penelitian dan Pengabdian Masyarakat Universitas Muhammadiyah Pekajangan Pekalongan}

Dalam program Indonesia sehat telah disepakati adanya dua belas indikator salah satunya yakni bayi mendapat Air Susu Ibu (ASI) Indokator Cakupan ASI di Kabupaten Pekalongan yaitu 57,2 persen dan diKota Pekalongan 57,2 persen terkait permasalahan pencapaian ASI Eksklusif diantaranya yakni permasalahan susu formula masih gencar dilakukan untuk bayi 0-6 bulan yang tidak ada masalah medis, masih banyaknya perusahaan yang memperkerjakan perempuan tidak memberi kesempatan bagi ibu yang memiliki bayi 0-6 bulan untuk melaksanakan pemberian ASI secara eksklusif. hal ini terbukti dengan belum tersedianya ruang laktasi dan perangkat pendukungnya, masih terbatasnya tenaga konselor ASI, belum maksimalkan kegiatan edukasi, sosialiasi, advokasi dan kampanye terkait pemberian ASI [6]

Inisiasi menyusu dini (IMD ) merupakan metode bayi yang harus aktif menemukan sendiri putting susu ibu, bukan ibu yang menyusui. metode ini dilakukan dengan cara meletakkan langsung bayi yang baru lahir di dada ibunya dan membiarkan bayinya untuk merayap menemukan sendiri putting susu ibunya untuk menyusu. metode ini di Indonesia telah dilakukan namun sayang sekali masih sering dilakukan kurang sempurna. Masih ada yang melakukan IMD dengan bayi yang telah dibungkus lebih dulu.Sehingga tidaak terjadi skin to skin antara ibu dan bayinya [7] kurangnya pengetahuan dari orangtua, keengganan untuk melakukan membuat IMD jarang dilakukan padahal metode ini mempunyai manfaat yang sangat besar untuk ibu dan bayinya.

Pelaksanaan IMD bermanfaat pada bayi diantara bayi dalam keadaan terjaga (periode reaktivitas pertama) dan merangsang produksi oksitosin yang membantu pengeluaran plasenta dan menghindari perdarahan postpartum, yang mendapat program IMD dapat secara dini belajar untuk memberikan rangsangan pada puting payudara sehingga meningkatkankan peluang suksesnya proses menyusu sejak dini [8] Proses penting yang terjadi adalah bayi akan mulai meremas-remas puting susu ibu, bertujuan merangsang supaya air susus ibu segera berproduksi dan bisa keluar [9]. Dampak tidak dilakukan IMD pada bayi adalah terjadinya kegagalan menyusui sehingga bayi tidak mendapatkan kolostrum yang bermanfaat untuk menurunkan angka kematian bayi. Disamping itu resiko tidak dilakukan IMD pada bayi adalah terjadinya kematian di jam pertama kelahirannya karena tidak bisa menyesuaikan dengan lingkungan sekitarnya [7]. Cakupan bayi baru lahir di Indonesia pada tahun 2019 yang mendapatkan Inisiasi Menyusu Dini ( IMD) yaitu 75,58 (Kemenkes, 2019), di Provinsi Jawa tengah 83,63, sedangkan di Kota Pekalongan sendiri 96,7 dan di Kabupaten Pekalongan 94,5 persen (DinKes, 2019).

Berdasarkan latar belakang tersebut pemberian air susu ibu segera dilakukan pada bayi setelah ibu melahirkan sangat penting untuk daya tahan tubuh bayi dan proses berikut merupakan penunjang untuk kelancaran produksi ASI pada ibu membuat peneliti tertarik untuk melakukan penilitian mengenai Hubungan Pemberian Inisiasi Menyusu Dini (IMD) Dengan Kelancaran Pengeluaran ASI.

\section{Metode}

Penelitian ini merupakan Penelitian kuantitatif melalui Literature Review. Artikel ini telah ditelaah kritis dengan menggunakan instrument JBI The Joanna Briggs Institute. Sasaran pada penelitian ini adalah ibu menyusui. 


\section{Prosiding Seminar Nasional Kesehatan Lembaga Penelitian dan Pengabdian Masyarakat Universitas Muhammadiyah Pekajangan Pekalongan}

\section{Hasil dan Pembahasan}

\section{Hasil}

1. Pemberian Inisiasi Menyusu Dini (IMD)

Tabel 3.1 Hasil Literature Review Data Pemberian IMD

\begin{tabular}{|c|c|c|c|c|c|c|}
\hline \multirow{3}{*}{ Penulis } & \multicolumn{2}{|c|}{ Artikel } & \multicolumn{4}{|c|}{ Kategori IMD } \\
\hline & Tahun & Negara & \multicolumn{2}{|c|}{ Dilakukan } & \multicolumn{2}{|c|}{ Tidak dilakukan } \\
\hline & & & $\mathrm{F}$ & $\%$ & $f$ & $\%$ \\
\hline $\begin{array}{l}\text { Nuzulul Rahmi } \\
\text { Merlani }\end{array}$ & 2019 & Indonesia & 38 & $63,3 \%$ & 22 & 36,7 \\
\hline $\begin{array}{l}\text { Etriyanti, Fenny } \\
\text { Fernando }\end{array}$ & 2019 & Indonesia & 29 & $82,9 \%$ & 6 & $17,1 \%$ \\
\hline $\begin{array}{l}\text { Hellen } \\
\text { Febriyanti, Wike } \\
\text { Sri Yohanna \& } \\
\text { Eva Nurida }\end{array}$ & 2018 & Indonesia & 24 & $80 \%$ & 6 & $20 \%$ \\
\hline $\begin{array}{l}\text { Arini } \\
\text { Purnamasari }\end{array}$ & 2019 & Indonesia & 26 & $68,4 \%$ & 12 & $31,6 \%$ \\
\hline $\begin{array}{l}\text { Andri Bahrun, } \\
\text { Atun Raudatul } \\
\text { Ma'rifah }\end{array}$ & 2014 & Indonesia & 41 & $73,2 \%$ & 15 & $26,8 \%$ \\
\hline Total & & & 219 & & & \\
\hline
\end{tabular}

Tabel 3.2 Hasil Literature Review Data Pemberian IMD

\begin{tabular}{llr}
\hline Kategori IMD & F & \% \\
\hline IMD & 158 & 72,1 \\
Tidak IMD & 61 & 27,8 \\
& & \\
\hline Jumlah & 219 & 100
\end{tabular}

Berdasarkan tabel 3.1 dan 3.2 di dapatkan hasil dengan responden 219 yang terdiri dari IMD dan tidak IMD dengan hasil masing-masing yang melakukan IMD 158 dengan 72,1\% sedangkan yang tidak melakukan IMD 61 dengan $27,8 \%$.

2. Kelancaran Air Susu ibu (ASI)

Tabel 3.3 Hasil Literature Review Kelancaran ASI

\begin{tabular}{|c|c|c|c|c|c|c|}
\hline \multirow[b]{2}{*}{ Renulis } & \multicolumn{2}{|c|}{ Artikel } & \multicolumn{4}{|c|}{ Kategori Kelancaran ASI } \\
\hline & Tahun. & Negara & \multicolumn{2}{|c|}{ bancar. } & \multicolumn{2}{|c|}{ Tidak Lancar } \\
\hline & & & $\mathrm{F}$ & $\%$ & $f$ & $\%$ \\
\hline $\begin{array}{l}\text { Nuzulul Rahmi } \\
\text { Merdani }\end{array}$ & 2019 & Indonesia & 26 & $43,3 \%$ & 34 & $56,7 \%$ \\
\hline $\begin{array}{l}\text { Etrixanti, Fenny } \\
\text { Fernando }\end{array}$ & 2019 & Indonesia & 27 & $77,1 \%$ & 8 & $22,9 \%$ \\
\hline $\begin{array}{l}\text { Hellen } \\
\text { Eebrixanti, Wike } \\
\text { Sri Yobanna \& } \\
\text { Eva Nurida }\end{array}$ & 2018 & Indonesia & 20 & $66,7 \%$ & 10 & $33,3 \%$ \\
\hline $\begin{array}{l}\text { Arini } \\
\text { Purnamasari }\end{array}$ & 2019 & Indonesia & 23 & $60,5 \%$ & 15 & $39,3 \%$ \\
\hline $\begin{array}{l}\text { Andri Bahrun, } \\
\text { Atun Raudatul } \\
\text { Márifah }\end{array}$ & 2014 & Indonesia & 29 & $51,8 \%$ & 27 & $48,2 \%$ \\
\hline Total & & & 219 & & & \\
\hline
\end{tabular}




\section{Prosiding Seminar Nasional Kesehatan Lembaga Penelitian dan Pengabdian Masyarakat Universitas Muhammadiyah Pekajangan Pekalongan

Tabel 3.4 Hasil Literature Review Kelancaran ASI

\begin{tabular}{lcc}
\hline Kelancaran ASI & F & \% \\
\hline Lancar & 125 & 57 \\
Tidak lancar & 94 & 43 \\
& & 100 \\
\hline Jumlah & 219 & 100 \\
\hline
\end{tabular}

Berdasarkan hasil analisa 5 artikel pada tabel 2 dalam kelancaran ASI di dapatkan hasil responden 219 dengan masing-masing jumlah Lancar dan tidak lancar, ASI yang Lancar 125 dengan 57\% sedangkan ASI Tidak Lancar yaitu 94 dengan $43 \%$.

3. Hubungan Pemberian Inisiasi Menyusu Dini (IMD) dengan Kelancaran Pengeluaran ASI

Tabel 3.5 Hasil Literature Review Hubungan inisiasi menyusu dini (IMD) dengan kelancaran pengeluaran ASI

\begin{tabular}{|c|c|c|c|}
\hline Penulis & Tahun & Judul & Pvalue \\
\hline $\begin{array}{l}\text { Nuzulul } \\
\text { Rahmi } \\
\text { Merlani }\end{array}$ & 2019 & $\begin{array}{l}\text { Analisis Faktor-faktor yang Berhubungan } \\
\text { Denngan Kelancaran ASI Pada ibu menyusui } \\
\text { Diwilayah Kerja Puskesmas Lhoong Kabupaten } \\
\text { Aceh Besar }\end{array}$ & 0,029 \\
\hline $\begin{array}{l}\text { Etriyanti, } \\
\text { Fenny } \\
\text { Fernando }\end{array}$ & 2019 & $\begin{array}{l}\text { Hubungan inisiasi menyusui dini (IMD) dengan } \\
\text { kelancaran produksi ASI pada ibu post section } \\
\text { Caesaria di Ruangan Kebidanan RSUD } \\
\text { Sawahluto }\end{array}$ & 0,000 \\
\hline $\begin{array}{l}\text { Hellen } \\
\text { Febriyanti, } \\
\text { Wike Sri } \\
\text { Yohanna \& } \\
\text { Eva Nurida }\end{array}$ & 2018 & $\begin{array}{l}\text { Kelancaran Produksi ASI pada ibu post partum } \\
\text { ditinjau dari Inisiasi Menyusu dini dan isapan } \\
\text { bayi }\end{array}$ & 0,009 \\
\hline $\begin{array}{l}\text { Arini } \\
\text { Purnamasari }\end{array}$ & 2019 & $\begin{array}{l}\text { Hubungan inisiasi menyusu dini dan frekuensi } \\
\text { menyusu dengan produksi ASI pada ibu } \\
\text { menyusui } 0-6 \text { bulan di Puskesmas Rantepao } \\
\text { Kabupaten Toraja Utara }\end{array}$ & 0,000 \\
\hline $\begin{array}{l}\text { Andri Bahrun, } \\
\text { Atun Raudatul } \\
\text { Ma'rifah }\end{array}$ & 2014 & $\begin{array}{l}\text { Hubungan inisiasi menyusi dini (IMD) dengan } \\
\text { kelancaran produksi Air susu ibu (ASI) Pada } \\
\text { ibu post partum di ruang nifas RSUD dr. } \\
\text { R.Goeteng Taroenadibrata Purbalingga }\end{array}$ & 0,001 \\
\hline
\end{tabular}

Berdasarkan tabel 3.5dapat diketahui bahwa dari 5 artikel menggunakan analisa uji chi-square menunjukkan ada hubungan antara pemberian inisiasi menyusu dini kelancaran pengeluaran ASI $p$ value $<0,05(0,000-0,029)$.

\section{Pembahasan}

1. Pemberian IMD

Berdasarkan literature review terhadap artikel 5 mengenai data pemberian IMD. Menurut data pemberian IMD terbanyak pada yang melakukan IMD yaitu dengan 


\section{Prosiding Seminar Nasional Kesehatan 2021 Lembaga Penelitian dan Pengabdian Masyarakat Universitas Muhammadiyah Pekajangan Pekalongan}

jumlah responden $158(72,1 \%)$. Hal ini sejalan dengan hasil penelitian [10] Hubungan Inisiasi Dini Dengan Produksi ASI Pada Ibu Menyusui Di Wilayah Kerja Puskesmas Nanggalo Padang dengan respoden terbanyak yang melakukan imd yaitu 42 ibu menyusui yang melakukan imd dengan presentase $59,5 \%$. penelitian ini juga sejalan dengan penelitian Dyah siwi Hetty \& Ika Yuni Susanti yang berjudul Inisiasi menyusu dini (IMD) Terhadap kelancaran ASI pada ibu menyusui bayi usia 0-1 bulan di puskesmas kutorejo 2021 dengan total responden 14 yang melakukan Inisiasi menyusu dini (IMD) 12 reponden dengan presentase 85,7\%. Inisiasi menyusu dini yaitu memberikan ASI kepada bayi baru lahir, tidak boleh dibersihkan terlebih dahulu dan tidak dipisahkan dari ibu. Pada inisiasi menyusu dini, ibu segera mendekap dan membiarkan bayi menyusu dalam 1 jam pertama kelahirannya (Roesli, 2008). Kenyataan dilapangan menujukkan bahwa hampir seluruh dari responden melakukan inisiasi menyusu dini karena tatalaksana IMD terdapat dalam Asuhan persalinana normal daan termasuk dalam program.

Inisiasi menyusu dini akan menentukan kesuksesan menyusui selanjutnya, ibu yang memberikan ASI dalam 1 jam pertama setelah melahirkan mempunyai peluang 2-8 kali lebih besar untuk memberikan ASI ekslusif. Kontak awal ini merupakan periode sensitif, sehingga apabila terlambat, perkembangan anak dan keberhasilan menyusui akan terganggu.

Sebagai tim kesehatan, kita harus memberikan penyuluhan dan informasi kepada masyarakat pentingnya inisiasi menyusu dini. Karena masih kuatnya kepercayaan keluarga dan masyarakat tentang kondisi ibu yang membutuhkan istirahat setelah melahirkan, dan ASI yang keluar pada hari pertama tidak baik untuk bayi. Memang tidak mudah mengubah persepsi masyarakat tentang hal tersebut, tapi jika diberikan gambaran manfaat inisiasi menyusu dini bias mengurangi terjadinya perdarahan dan manfaat dari inisiasi membuat produksi ASI Lancar yang mengurangi pembiayaan rumah tangga. Maka akan membantu keberhasilan pelaksanaan Inisiasi menyusu dini dan program ASI Eksklusif Selma 6 bulan.

\section{Kelancaran ASI}

Berdasarkan literature review terhadap artikel 5 mengenai data kelancaran ASI. Menurut data kelancaran ASI terbanyak pada yang melakukan ASI lancar yaitu responden 125 (57\%). Hal ini sejalan dengan hasil penelitian Anis Setyowati 2018 Hubungan Inisiasi Menyusui Dini dengan Produksi ASI Selama 6 Bulan Pertama yaitu sebanyak 31 responden dengan presantase 80,6\%. ASI merupakan makanan terbaik berupa cairan yang disekresikan oleh kedua kelenjar payudara ibu untuk mempengaruhi kebutuhan gizi bayi yang melindunginya dalam melawan serangan penyakit [10]. Penelitian ini juga sejalan dengan penelitian Dyah Hetty Siwi \& Ika Yuni Susanti yang berjudul Inisiasi menyusu dini (IMD) Terhadap kelancaran ASI pada ibu menyusui bayi usia 0-1 bulan di puskesmas kutorejo tahun 2021 hasil penelitian Dyah Hetty Siwi \& Ika Yuni Susanti dari 14 responden, diketahui bahwa hamper seluruh reponden 11 orang $(78,6 \%)$ keluar ASI nya Lancar, dan 3 orang $(21,4 \%)$ keluaran ASI nya tidak Lancar. 


\section{Prosiding Seminar Nasional Kesehatan 2021 Lembaga Penelitian dan Pengabdian Masyarakat Universitas Muhammadiyah Pekajangan Pekalongan}

Beberapa kritireia yang dipakai sebagai patokan untuk mengetahui jumlah ASI lancar atau tidak adalah: ASI yang banyak dapat merembes keluar melalui putting, sebelum disusukan payudara terasa tegang, jika ASI cuku, setelah menyusu bayi akan tertidur/tenang selama 3-4 jam, sebelum menyusui payudara terasa penuh dan setelah menyusui terasa longgar, bayi kencing lebih sering sekitar 8 kali dalam 24 jam, bayi mendapatkan ASI memadaai umumnya lebih tenang, tidak rewel dan dapat tidur pulas (Wulan,2011).

Tanda pasti bahwa ASI memadaai dapat terlihat pada penambahan berat badan bayi yang baik, dalam keadaan normal usia 0-5 hari biasanya berat badan bayi akan menurun. Setelah usia 10 hari berat badan bayi akan kembali seperti saat lahir. Secara alamiah ASI di produksi dalam jumlah yang sesuai dengan kebutuhan bayi (Wulan,2011).

Inisiasi menyusu dini (IMD), penghisapan oleh bayi segera lahir dapat membantu mempercepat pengeluaran ASI dan memastikan kelangsungan pengeluaran ASI (Sarwono, 2009). Frekuensi menyusi atau produksi ASI prinsipnya based of deman, jika makin sering disusui, maka makin banyak ASI yang diprodduksi. Namun apabila ASI yang diproduksi tidak dikeluarkan, maka laktasi akan tertekan (mengalami hambatan) karena terjadi pembengkakan alveoli dan sel keranjang tidak dapat berkontraksi (Saleha, 2009).

Air susu ibu (ASI) adalah makanan terbaik untuk bayi, tidak satuoun makanan lain yanh dapat menggantikan ASI, karena ASI mempunyai kelebihan yang meliputi tiga aspek yaitu aspek gizi, aspek kekebalan dan aspek kejiwaan berupa jalinan kasih saying untuk perkembangan mental dan kecerdasan anak (DepKes RI, 2005). Diharapkan tenaga kesehatan banyak memberikan penyuluhan tentang ASI, bagaimana ibu mempertahankan produksi ASI nya agar tetap lancar dan bisa memberikan ASI eksklusif selama 6 bulan tanpa makanan tambahan pendambing ASI.

3. Hubungan pemberian inisiasi menyusu dini dengan kelancaran pengeluaran ASI

Berdasarkakan literature review terhadap 5 artikel dengan hubungan pemberian inisiasi menyusu dini dengan kelancaran pengeluaran ASI dengan menggunakan analisa artikel didapatkan jumlah $P$ value $<0,05$ yang artinya ada hubungan antara pemberian inisiasin menyusu dini dengan kelancaran pengeluaran ASI penelitian ini sejalan dengan penelitian [7] dengan judul hubungan pemberian inisiasi menyusu dini dengan kelancaran pengeluaran ASI dengan hasil $p$ value 0,006 yang menjelaskan adanya hubungan pemberian inisiasi menyusu dini dengan kelancaran pengeluaran ASI

Inisiasi menyusu dini adalah memberikan kesempatan bayi menyusu sendiri segera setelah lahir dengan meletakkan bayi di dada atau perut ibu dan kulit bayi melekat pada kulit ibu stidaknya kurang lebih 1 jam samapai bayi menyusu sendiri. Imd dapat membantu dalam keberlangsungan pemberian ASI secara Ekslusif (ASI saja) dan lama menyusui serta akan terpenuhi kebutuhan bayi hingga usia 2 tahun dan mencegah anak kurang gizi [7].

Meskipun inisiasi menyusu dini (IMD) telah diketahui banyak manfaatnya, namum pelaksanaan IMD ternyata masih sedikit dilakukan padahal ASI sejak dini 


\section{Prosiding Seminar Nasional Kesehatan 2021 Lembaga Penelitian dan Pengabdian Masyarakat Universitas Muhammadiyah Pekajangan Pekalongan}

sangat bermanfaat untuk tumbuh kembang bayi, namun beberapa ibu masih banyak yang tidak langsung bias menyusui bayinya setelah melahirkan. beberapa ibu membutuhkan waktu puluhan menit hingga satu jam sampai ASI-nya keluar.faktorfaktor yang dapat mempengaruhi kelancaran pengeluaran ASI diantaranya pertama adalah jilatan bayi atau hisapan bayi pada putting ibu akan merangsang keluarnya oksitosin merangsang pengaliran ASI dari payudara, sehingga ASI matang (yang berwarna putih) dapat lebih cepat keluar. dengan menyusui lebih dini terjadi perangsangan putting susu, terbentuknya prolactin oleh hipofisis sehingga sekresi ASI lebih lancar [7]

Inisiasi menyusu dini (IMD) merupakan tahap awal yang sangat baik bila ingin menjalankan program ASI Eksklusif. Proses pembentukan atau produksi ASI pada seorang ibu menyusui dikenal dua refllek yang masing-masing berperan sebagai pembentukkan dan pengeluaran ASI yaitu reflex protaktin dan reflex oxsytosin. Hormon-hormon ini sangat perlu untuk pengeluaran permulaan dan pemeliharaan penyediaan air susu selam menyusui. Berkurangnya rangsangan menyusui oleh bayi misalnya bila kekuatan isapan kurang, frekuensi isapan yang kurang dan singkatnya waktu menyusui ini berarti pelepasan prolactin dari hipofese berkurang sehingga pembuatan air susu berkurang karena diperlukan kadar prolactin yang cukup untuk mempertahankan pengeluaran air susu mulai sejak minggu pertama kelahiran. Oksitosin bekerja pada sel-sel moepitelium pada alveoli kelenjar mamae.Hormone ini berfungsi memacu kontraksi otot polos yang ada didinding alveolus dan dinding salurang sehingga ASI dipompa keluar. Makin sering menyusui, pengosongan alveolus dan saluran semakin baik sehingga kemungkinan terjadinya bendungan susu semakin kecil dan menyusui akan semakin lancar. Jadi peranan prolactin dan oksitosin mutlak diperlukan dalam laktasi [11].

\section{Kesimpulan}

Berdasarkan pemberian IMD, sebagian besar responden melakukan Imd yaitu sebanyak 72,1\%. Berdasarkan Kelancaran ASI, sebagian besar responden $57 \%$ mendapatkan Kelancaran ASI.Berdasarkan hubungan pemberia inisiasi menyusu dini dengan kelancaran pengeluaran asi $\boldsymbol{\rho}$ value $<0,05$ maka dapat disimpulkan bahwa ada Hubungan Pemberian Inisiasi Menyusu Dini Dengan Kelancaran Pengeluaran ASI

\section{Referensi}

[1] Dinas Kesehatan Provinsi Jawa Tengah (2019). Profil Kesehatan Jawa Tengah. Jateng Gayeng

[2] Khasanah Nur .(2011).ASI Atau Susu Formula Ya? : Panduan Lengkap Seputar dan Susu Formula. Yogyakarta.Flash Books

[3] Prasetyono, D. S. (2012). Buku Pintar Asi Esk/usif. Jogjakarta: Diva Press .

[4] Nirwana Ade Benih.(2014).ASI susu Formula kandungan dan manfaat ASI \& Susu formula.Yogyakarta.Nuha Medika 


\section{Prosiding Seminar Nasional Kesehatan $\mathbf{2 0 2 1}$ Lembaga Penelitian dan Pengabdian Masyarakat Universitas Muhammadiyah Pekajangan Pekalongan}

[5] Widuri, H. (2013). Cara Mengelola Asi Esklusif Bagi Ibu Bekerjs. Yogyakarta: Gosyen Publishing.

[7] Nurbaiti, M. (2020). Hubungan Pemberian Inisiasi Menyusu Dini (IMD) Dengan kelancaran Pengeluaran Asi. Seminar Nasional Keperawatan, 52-58.

[6] Nuzulul Rahmi, M. (2019). Analisis Faktor-Faktor Yang Berhubungan Dengan Kelancaran Pengeluaran Asi Pada Ibu Menyusui Di wilayah Kerja Puskesmas Lhoong Kabupaten Aceh Besar. Journal Of Healthcare Technology And Medicine, Vol .5 No.2, 297-307

[8] Profil Kesehatan Indonesia.(2019).Profil Kesehatan Indonesia.Kementrian Kesehatan RI

[9] Yusefni Eida (2012) Hubungan Inisiasi Menyusu Dini Dengan Produksi ASI Pada Ibu Menyusui Di Wilayah Kerja, Puskesmas Nanggalo Padang Jurnal politeknik Kesehatan Kemenkes Padang

[10] Setyowati Anis (2018) Hubungan Inisiasi Menyusu Dini dengan Produksi ASI Selama 6 Bulan Pertama.Jurnal Manajemen Kesehatan Yayasan RS.Dr.Soetomo Vol. 4 No. 1

[11] Wiji, R. N. (2014). Asi Dan Panduan Ibu Menyusui. Yogyakarta: Nuha Medika. 